\title{
KEBIJAKAN HUKUM PIDANA DALAM UPAYA PENANGGULANGAN TINDAK PIDANA UNTUK MENGURANGI OVERCROWDED LEMBAGA PEMASYARAKATAN PADA MASA PANDEMI COVID-19
}

\author{
Andika Oktavian Saputra, Sylvester Enricho Mahardika, Pujiyono \\ Fakultas Hukum, Universitas Diponegoro, Semarang \\ peter.enricho@gmail.com
}

\begin{abstract}
Abstrak
Peningkatan jumlah penghuni lembaga pemasyarakatan dapat memicu adanya permasalahan overcrowded. Overcrowded di lembaga pemasyarakatan juga rentan terhadap penularan Covid-19 yang saat ini masif terjadi. Dikeluarkannya kebijakan pemerintah berupa Kebijakan oleh Menteri Hukum dan Ham berupa Keputusan Menteri Hukum dan Ham No M.HH-19.PK.01.04.04 Tahun 2020, dan juga Permenkumham No 10 Tahun 2020 merupakan suatu hal yang tepat dan memperoleh dampak yang positif bagi keberlangsungan sistem pemasyarakatan. Dari pengurangan narapidana di dalam Lapas melalui Asimilasi dan Integrasi untuk mencegah COVID-19 bagi narapidana, berhasil menurunkan angka Overcrowded Lapas. Tujuan penelitian ini adalah untuk mengetahui upaya penanggulangan overcrowded pada lembaga pemasyarakatan ditengah munculnya wabah virus covid19, metode yang digunakan adalah yuridis normatif. Hasil penelitian menunjukkan kebijakan mengurangi masa pidana akibat adanya pandemic COVID-19 untuk memberi asimilasi dan integrasi kepada narapidana setelah memenuhi syarat-syarat tertentu merupakan kebijakan yang progresif.
\end{abstract}

Kata kunci: Penanggulangan; Overcrowded; Lembaga Pemasyarakatan; Covid-19 


\title{
CRIMINAL LAW POLICY IN CRIMINAL TREATMENT EFFORTS TO REDUCE OVERCROWDED INSTITUTIONS IN THE PANDEMIC TIME OF COVID-19
}

\begin{abstract}
The increase in the number of residents in correctional institutions can lead to overcrowded problems. Overcrowded in prisons is also vulnerable to the massive transmission of Covid-19, which is currently occurring. The issuance of government policies in the form of policies by the Minister of Law and Human Rights in the form of Decree of the Minister of Law and Human Rights No. M.HH-19.PK.01.04.04 of 2020, and also Permenkumham No. 10 of 2020 is the right thing and has a positive impact on sustainability correctional system. From the reduction of prisoners in prisons through assimilation and integration to prevent COVID-19 for inmates, it has succeeded in reducing the number of Over-crowded prisons. The purpose of this study is to determine the efforts to overcome overcrowded in correctional institutions amid the emergence of the Covid19 virus outbreak, the method used is juridical normative. The results showed that the policy of reducing the criminal period due to the COVID-19 pandemic to assimilate and integrate prisoners after fulfilling certain conditions is a progressive policy.
\end{abstract}

Keywords: revention; Overcrowded; Correctional Institution; Covid-19. 


\section{A. PENDAHULUAN}

Akhir-akhir ini, salah satu yang hangat diberitakan di ruang publik seperti media online dan elektronik adalah mengenai pembebasan narapidana. Keputusan itu menuai pro dan kontra di tengah tengah masyarakat serta dihadapkan pada penolakan dari sejumlah pihak, apalagi aktivis anti korupsi dan sebagian masyarakat. Pembebasan narapidana kali ini merupakan bagian dari upaya pemerintah memutus penyebaran Coronavirus disease (COVID-19) di lingkungan lembaga pemasyarakatan (lapas) dan rumah tahanan negara (rutan). Kebijakan yang dikecualikan untuk narapidana narkoba dan korupsi itu juga dibuat karena kondisi lapas dan rutan yang melebihi kapasitas.

Sebelumnya, Menteri Hukum dan HAM RI, H. Yasonna Laoly, menerbitkan Peraturan Menteri Hukum dan HAM Nomor 10 Tahun 2020 dan Keputusan Menteri Hukum dan HAM Nomor M.HH-19.PK/01.04.04 tentang Pengeluaran dan Pembebasan Narapidana dan Anak Melalui Asimilasi dan Integrasi Dalam Rangka Pencegahan dan Penanggulangan Penyebaran COVID-19.

Berdasarkan aturan tersebut, Kementerian Hukum dan HAM (Kemenkumham) membebaskan narapidana dan Anak sekitar 30.000 orang. Yasonna mengatakan hal tersebut guna mengantisipasi penularan COVID-19 serta mengurangi kelebihan kapasitas di tengah pandemi COVID-19. Menurut data Direktorat Jenderal (Ditjen) Pemasyarakatan hingga Selasa (31/3), total Warga Binaan Pemasyarakatan (WBP) di rutan dan lapas di Indonesia sebanyak 270.386 orang, sementara kapasitas lapas dan rutan di Indonesia hanya mampu menampung 131.931 orang. Melihat kondisi itu, narapidana dan tahanan berpotensi terpapar COVID-19. Hal itu karena narapidana dan tahanan yang berjejal dan tak dapat menjaga jarak di lapas dan rutan.

Lebih lanjut, dari aturan tersebut Ditjen Pemasyarakatan memprediksi akan mengurangi angka serta menghemat anggaran sebesar Rp. 260 miliar menyusul pembebasan 30.000 narapidana dan Anak tersebut. Direktur Pembinaan Narapidana dan Latihan Kerja Produksi Ditjen Pemasyarakatan, Yunaedi, menuturkan angka tersebut didapat dari hasil perkalian antara biaya hidup WBP sebesar Rp 32.000/hari yang dikali dengan 270, yakni jumlah hari tersisa dari April -Desember 2020 dan dikali 30.000 orang narapidana yang akan bebas. Lalu, berapa total uang negara yang harus dikeluarkan untuk tahanan dan narapidana? Saat ini jumlah tahanan dan narapidana sebanyak 200 ribuan 
orang. Bila dikalikan Rp. 32 ribu/hari dan dikalikan 365 hari, dalam setahun Anggaran Pendapatan Belanja Negara harus dikucurkan sebesar triliunan rupiah untuk makan tahanan/narapidana.

Selain untuk mengurangi jumlah narapidana di dalam lapas yang memang kapasitasnya terbatas, para narapidana adalah kelompok yang rentan terkena COVID-19. Kendati kasus positif COVID-19 di penjara saat ini masih rendah, kekhawatiran penyebaran di penjara di mana para narapidana berbagi sel, tempat mandi, dan ruang makan yang sama. Banyak negara mengikuti langkah tersebut yang dinilai sebagai alternatif dalam situasi darurat sebagai respons terhadap epidemi virus Corona. Langkah ini tidak hanya dilakukan Pemerintah Indonesia, namun sejumlah negara lain juga telah memutuskan membebaskan sebagian narapidana demi mengurangi penyebaran COVID19 di penjara, seperti Iran, Afghanistan, Brazil, termasuk Amerika Serikat. Negara Iran membebaskan 95.000 narapidana, Brazil membebaskan 34.000 narapidana, Prancis 66.300 narapidana, Yunani juga sudah melakukan hal serupa akan membebaskan total 15 ribu narapidana. Tunisa mengumumkan akan membebaskan 1.420 tahanan dalam bentuk amnesti untuk meringankan kepadatan di penjara dan Afghanistan akan membebaskan 10.000 tahanan berusia di atas 55 tahun untuk membendung penyebaran Virus Corona.

Sejauh ini telah dilakukan beberapa penelitian yang menyoroti tentang overcrowded lembaga pemasyarakatan ditengah wabah virus covid-19 yang menyerang seluruh dunia termasuk Indonesia, diantaranya penelitian oleh Muhar Jaya dengan judul Kebijakan Hukum Pidana terhadap Kedaruratan di Situasi Pandemi COVID-19 Sebagai Alasan Pembebasan Bersyarat. Penelitian ini menunjukkan kebijakan guna mencegah penularan dan penyebaran COVID-19 bukan solusi yang tepat dan hanya bersifat sementara. Dalam konsepsi Pendekatan-Kebijakan seharusnya kebijakan pembebasan bersyarat disituasi pandemiCOVID-19 ini berupaya untuk mengatasi COVID-19 sebagai masalah-masalah sosial dan masalah kemanusian serta merupakan bagian dari upaya memberikan perlindungan kepada masyarakat. Sehingga pembebasan narapidana jangan hanya difokuskan untuk sekedar mencegah COVID-19 dan over kapasitas penjara, namun tetap harus memperhatikan aspek keadilan dan efek jera sebagai tujuan pemidanaan yaitu 
untuk memperbaiki pelaku agar menjadi baik dan tidak mengulangi kejahatannya kembali. ${ }^{1}$

Penelitian lain telah dilakukan oleh Anwar dengan judul penelitian "Asimilasi dan Peningkatan Kriminalitas Di Tengah Pembatasan Sosial Berskala Besar Pandemi Corona", penelitian menunjukkan bahwa kebijakan tersebut justru menimbulkan kerawanan keamanan ditengah masyarakat, dalam kondisi saat ini yang tengah panik dengan kerawanan social. Hal tersebut dikarenakan kondisi ekonomi saat ini yang carutmarut ditengah pandemic corona virus atau COVID-19, pengangguran yang banyak, hidup susah sehingga menjadikan potensi kriminologinya besar sekali. Maka tak heran sejumlah napi nekat berulah kembali. ${ }^{2}$

Judul berbeda yang ditulis oleh Appludnopsanji yaitu "Problematika Kebijakan Pembebasan Narapidana sebagai Upaya Penanggulangan COVID-19 di Indonesia" mengungkap bahwa upaya pemerintah dalam menanggulangi COVID-19 di Lembaga Pemasyarakatan yang telah "overcrowded" adalah dengan mengambil kebijakan pembebasan narapidana melalui jalur asimilasi dan hak integrasi. Namun, kebijakan ini tidak lepas dari adanya problematika yang hadir di tengah-tengah masyarakat, seperti pengulangan kembali tindak pidana yang dilakukan oleh mantan narapidana yang telah dibebaskan berdasarkan kebijakan ini. ${ }^{3}$

Untuk diketahui bersama, jumlah narapidana yang menghuni seluruh fasilitas rutan dan lapas (semua kelas) di Indonesia berjumlah sekitar 252-an ribu. Jumlah ini hampir $60 \%$ melebihi kapasitas tempat penampungan narapidana yang seyogianya hanya bisa menampung 170-an ribu narapidana. Artinya, ada overcapacity, bahkan bisa mencapai $300 \%$ di beberapa tempat yang ada di Indonesia.

Melihat kenyataan di atas, tentu kita miris sebagai warga negara bahwa pelaku kejahatan (tidak termasuk yang belum tersentuh hukum) di Indonesia sangatlah banyak. Hal ini tidak akan mungkin bisa disepadankan dengan kondisi penjara di Belanda yang penghuninya hampir tidak ada dan gedung penjara terancam dirobohkan di beberapa kota.

\footnotetext{
${ }^{1}$ Muhar Jaya. "Kebijakan Hukum Pidana terhadap Kedaruratan di Situasi Pandemi COVID-19 Sebagai Alasan Pembebasan Bersyarat.” Halu Oleo Legal Research 2(3), 2020, hal 309. DOI: 10.33772/holresch.v2i3.15482

${ }^{2}$ Mohamad Anwar, “Asimilasi dan Peningkatan Kriminalitas Di Tengah Pembatasan Sosial Berskala Besar Pandemi Corona”, Jurnal Adalah Buletin Hukum dan Keadilan 4 (1), 2020, hal 35. DOI: $10.15408 /$ adalah.v4i1.15504

${ }^{3}$ Appludnopsanji, Hari Sutra Disemadi. "Problematika Kebijakan Pembebasan Narapidana sebagai Upaya Penanggulangan COVID-19 di Indonesia." Wawasan Yuridika 4(2), 2020, hal 131. DOI: 10.25072/jwy.v4i2.369
} 
Penghuni rutan dan lapas yang melebihi kapasitas bukan saja tidak manusiawi, tetapi juga melanggar kebijakan menjaga jarak sosial.

Melihat permasalahan mendasar yang tampak riil adalah adanya kelebihan hunian narapidana di lapas dan rutan hampir seluruh Indonesia. Hal itu membuat lapas dan rutan rentan sangat terhadap penyebaran virus Corona. Beberapa kebijakan dalam rangka mengurangi overcapacity tampaknya telah dilakukan oleh pemerintah, antara lain dengan pembuatan kamar baru, renovasi bangunan, hingga pembangunan lapas baru yang mempunyai tujuan utama menambah daya tampung narapidana. ${ }^{4}$ Penelitian ini lebih menekankan pada upaya kebijakan hukum pidana dan upaya penanggulangan tidank pidana pada masa pandemic COVID 19 di Lembaga Pemasyarakatan dibandingkan dengan penelitian sebelumnya. Tujuan penelitian ini adalah untuk mengetahui upaya penanggulangan overcrowded pada lembaga pemasyarakatan ditengah munculnya wabah virus COVID 19.

\section{B. PERMASALAHAN}

1. Bagaimanakah kebijakan hukum pidana terhadap penanggulangan tindak pidana dalam hukum positif Indonesia pada masa pandemi COVID-19?

2. Bagaimanakah upaya mengurangi overcrowded Lembaga Pemasyarakatan Pada Masa Pandemi COVID-19?

\section{METODE PENELITIAN}

Metode yang digunakan dalam penelitian ini adalah metode yuridis empiris. Penelitian yurdis normatif adalah "dengan berbasis pada ilmu hukum normatif yang mengkaji implementasi sistem-sistem peraturan hukum positif dalam pelaksanaannya di masyarakat dengan memadukan data dan fakta yang terjadi, yang mana penelitian ini sering disebut juga dengan penelitian bekerjanya hukum (law in action”). Pokok kajiannya adalah "pelaksanaan atau implementasi ketentuan hukum positif dan kontrak secara faktual pada setiap peristiwa hukum tertentu yang terjadi dalam masyarakat guna mencapai tujuan yag telah ditentukan". 5

${ }^{4}$ https://sulsel.kemenkumham.go.id/berita-kanwil/berita-upt/5288-menyoal-over-kapasitas-penjara-di-tengahtengah-pandemi-covid-19. diakses pada 21 Desember 2020 pukul 12:00

${ }^{5}$ Taufani, Suteki . "Metodolocgi Penelitian Hukum (Filsafat, Teori, dan Praktik).” (Depok: PT RajaGrafindo Persada. 2018), hal 79 


\section{HASIL DAN PEMBAHASAN}

\section{Kebijakan Hukum Pidana Terhadap Penanggulangan Tindak Pidana Dalam Hukum Positif Indonesia Pada Masa Pandemi COVID-19}

Beberapa waktu lalu Yasonna Laoly selaku Menkumham membuat suatu kebijakan publik pada bidang pemasyarakatan dengan membuat kebijakan melalui Keputusan Menteri Hukum dan Ham no M.HH-19.PK.01.04.04 Tahun 2020, tentang pengeluaran dan pembebasan narapidana dan anak melalui asimilasi dan penanggulangan penyebaran COVID-19. Yang dimana dalam Kepmenkumham tersebut merupakan salah satu upaya pencegahan dan penyelamatan narapidana dan anak yang berada di dalam lembaga pemasyarakatan dan Rutan dalam pencegahan dari COVID-19. Pengeluaran ini dilakukan dan diberikan kepada seluruh narapidana yang ada di seluruh Indonesia dengan krieria dan ketentuan tertentu. Pembebasan bersyarat dan pengeluaran yang dilakukan melalui asimilasi dilakukan secara serentak dengan melalui Permenkumham No 10 tahun 2020 tentang syarat pemberian asimilasi dan hak integrasi bagi narapidana dan anak dalam rangka pencegahan dan penanggulangan penyebaran COVID-19. Dalam kepmen itu dijelaskan bahwa sejumlah ketentuan bagi narapidana dan anak yang dibebaskan melalui asimilasi. Pertama, narapidana yang dua pertiga masa pidananya jatuh sampai dengan 31 Desember 2020, dan anak yang setengah masa pidananya jatuh sampai dengan 31 Desember 2020. ${ }^{6}$ Fenomena Overcrowded di Lembaga Pemasyarakatan tidak terlepas dari sistemperadilan pidana yang berlaku di IndonesiaPenegakan hukum pidana yang diatudalam Kitab Undang-Undang Hukum Pidana(KUHP) menerapkan hukuman penjarasebagai bentuk hukuman utama. ${ }^{7}$

Upaya atau kebijakan untuk melakukan pencegahan dan penanggulangan kejahatan termasuk bidang "kebijakan kriminal" (criminal policy). Kebijakan kriminal ini pun tidak terlepas dari kebijakan yang lebih luas, yaitu kebijakan sosial (social policy) yang terdiri dari upaya/kebijakan untuk kesejahteraan sosial (social walfare policy) dan kebijakan untuk perlindungan masyarakat (social defence policy). Dengan demikian sekiranya kebijakan penanggulangan kejahatan (politik kriminal) dilakukan dengan menggunakan

${ }^{6}$ Bayu Rizky. "Dampak Positif Kebijakan Asimilasi Dan Integrasi Bagi Narapidana Dalam Pencegahan Dan Penaggulangan Covid-19.” Jurnal Ilmu Hukum dan Humaniora 7(3),2020. hal. 655. DOI: 10.31604/justitia.v7i3.655$\underline{665}$

${ }^{7}$ Graciella Patras. "Kajian Yuridis Tentang Overcrowded Yang Terjadi Di Lembaga Pemasyarakatan Kelas Ii A Manado Berdasarkan Peraturan Menteri Hukum Dan Hak Asasi Manusia Nomor 11 Tahun 2017”. Jurnal Lex Et Societatis 8(1), 2020. hal 340. DOI: http://dx.doi.org/10.30641/kebijakan.2019.V13.339-358 
sarana penal (hukuman) maka kebijakan hukum pidana (penal policy) khususnya dalam kebijakan yudikatif/aplikatif (penegakan hukum pidana in concerto) harus memerhatikan dan mengarah pada tercapainya tujuan dan kebijakan sosial itu, berupa social welfare dan social defence. ${ }^{8}$ Tingkat hunian cenderung sebanding Rutan. Hal meningkat setiap tahun tidak dengan jumlah Lapas dan ini berdampak pada gangguan keamanan dan ketertiban, kesehatan, dan efektivitas pelaksanaan pembinaan. Jika kondisi kepenuhsesakan ini tidak mendapat perhatian serius dan menemukan solusi mengatasinya akan berdampak pada situasi yang lebih serius yaitu bencana kemanusiaan. ${ }^{9}$

Tindak pidana perlu dicegah dan ditanggulangi demi tegaknya hukum, dan upaya atau kebijakan yang dapat dilakukan untuk mencegah dan menanggulangi kejahatan tersebut ialah melalui upaya atau politik kriminal (criminal policy). Politik kriminal dapat dilakukan dengan 2 (dua) upaya. Upaya pertama menggunakan upaya penal (penal policy) atau upaya hukum pidana atau kebijakan hukum pidana, dan upaya kedua menggunakan upaya non penal (non-penal policy) atau upaya kebijakan di luar hukum pidana. Pada dasarnya penal policy lebih menekankan pada tindakan represif (pemberantasan) setelah terjadinya suatu tindak pidana, sedangkan non penal policy lebih menekankan pada tindakan preventif (pencegahan) sebelum terjadinya suatu tindak pidana. Penanggulangan kejahatan melalui upaya penal adalah penerapan hukum pidana, maka dasarnya adalah tidak lain apa yang diatur dalam KUHP, khususnya Pasal 10 KUHP yang mengatur tentang jenis-jenis pidana. Disamping itu, penggunaan sanksi pidana dapat juga dilakukan melalui peraturan perundang-undangan yang mengatur ketentuan pidana didalamnya, sebagaimana dimaksud dalam Pasal 103 KUHP. ${ }^{10}$ Dengan demikian kebijakan hukum pidana terhadap penanggulangan tindak pidana dalam hukum positif Indonesia meliputi; kebijakan pidana, kebijakan kriminal, dan kebijakan pertanggungjawaban pidana.

\section{a.1. Kebijakan Pidana}

Pada hakikatnya, kebijakan hukum pidana (penal policy) dapat dioperasionalkan melalui 3 (tiga) tahap yaitu : Pertama tahap formulasi (kebijakan

\footnotetext{
${ }^{8}$ Moh Hatta, "Kebijakan Politik Kriminal Penegakan Hukum Dalam Rangka Penanggulangan Kejahatan"(Yogyakarta: Pustaka Pelajar 2010), hal 37

${ }^{9}$ Padmono Wibowo. “ Pentingnya Mitigasi Risiko Dampak Kepenuhsesakan pada Lapas dan Rutan di Indonesia” . Jurnal Ilmiah Kebijakan Hukum 14(2), 2020. hal 263. DOI: http://dx.doi.org/10.30641/kebijakan.2020.V14.263-283
}

${ }^{10}$ M. Hamdan, “Politik Hukum Pidana” (Jakarta: PT Raja Grafindo Persada 1997), hal. 28 
legislatif) yaitu tahap perencanan atau perumusan perundang-undangang pidana. Tahap ini merupakan tahap awal yang paling strategis dari keseluruhan proses operasionalisasi hukum pidana, serta yang menjadi dasar, landasan dan pedoman bagi tahap-tahap berikutnya yaitu tahap aplikasi dan tahap eksekusi. Kesalahan pada tahap formulasi merupakan kesalahan strategis yang dapat menghambat bagi tahap aplikasi dan eksekusi dalam kebijakan hukum pidana. Kedua, tahap aplikasi yaitu tahap penerapan dari ketentuan perundang-undangan pidana yang telah dilanggar. Ketiga, tahap eksekusi yaitu tahap pelaksanaan dari putusan pengadilan atas perbuatan pidana yang telah memperoleh kekuatan hukum tetap. ${ }^{11}$

Dalam arti luas, kebijakan hukum pidana dapat mencakup ruang lingkup kebijakan dibidang hukum pidana materiel, dibidang hukum pidana formal dan di bidang pelaksana pidana. Oleh karena itu upaya penanggulangan kejahatan dapat ditempuh melalui pendekatan kebijakan, dalam arti :

a. Ada keterpaduan (integralitas) antara politik kriminal dan politik sosial

b. Ada keterpaduan (integralitas) antara upaya penanggulangan kejahatan dengan penal non penal.

Keseluruhan tahap kebijakan penanggulangan kejahatan dengan hukum pidana, tahap kebijakan formulasi merupakan tahap yang paling strategis. Pada tahap formulasi inilah disusun semua "perencanaan" (planning) penanggulangan kejahatan dengan sistem hukum pidana. Keseluruhan sistem hukum pidana yang dirancang itu pada intinya mencakup tiga masalah pokok dalam hukum pidana, yaitu masalah perumusan tindak pidana (kriminalisasi), pertanggungjawaban pidana, dan aturan pidana atau pemidanaan. ${ }^{12}$

\section{a.2. Kebijakan Kriminal}

Apabila melihat berbagai kepustakaan ilmu hukum pidana dan turunan ilmunya, politik kriminal diistilah lainkan dengan kebijakan kriminal. Politik kriminal mempunyai keterkaitan dengan politik sosial, yakni usaha dari masyarakat atau negara untuk meningkatkan kesejahteraan warganya. ${ }^{13}$

\footnotetext{
${ }^{11}$ Teguh Prasetyo dan Abdul Halim Barkatullah, "Politik Hukum Pidana: Kajian Kebijakan Kriminalisasi dan Dekriminalisasi"(Yogyakarta : Pustaka Pelajar, 2005), hal. 22

${ }^{12}$ Barda Nawawi Arief, "Kebijakan Legislatif Dalam Penanggulangan Kejahatan Dengan Pidana Penjara," (Yogyakarta: Genta Publishing, 2010), hal. 223

${ }^{13}$ IS. Heru Permana, “Politik Kriminal,"(Yogyakarta: Universitas Atma Jaya, 2011), hal. 19
} 
Sudarto membagi pengertian poltik kriminal dalam tiga pengertian. Pertama, dalam pengertian sempit, politik kriminal adalah keseluruhan asas metode yang menjadi dasar dari reaksi terhadap pelanggaran hukum yang berupa pidana. Kedua, dalam pengertian lebih luas, politik kriminal adalah keseluruhan fungsi dari aparatur penegak hukum, termasuk cara kerja pengadilan dan polisi. Ketiga, dalam pengertian paling luas, politik kriminal adalah keseluruhan kebijakan yang dilakukan melalui peraturan perundang-undangan dan badan resmi yang bertujuan untuk meneggakkan norma-norma sentral dari masyarakat. Selain itu Sudarto memberikan pengertian secara praktis, menurutnya politik kriminal adalah "segala usaha yang rasional dari masyarakat untuk menanggulangi kejahatan". ${ }^{14}$

Tujuan akhir dari kebijakan kriminal adalah perlindungan masyarakat, atau tercapainya kesejahteraan masyarakat. Berdasarkan konsep pemikiran itu maka menurut Barda Nawawi perlu dikembangkan kebijakan integral antara kebijakan penal dengan kebijakan non penal. Karena kebijakan kriminal sebagai upaya penanggulangan kejahatan tidak hanya memandang kebijakan penal sebagai satusatunya upaya yang paling efektif dalam penanggulangan kejahatan. Akan tetapi upaya-upaya non penal justru harus diterapkan pada posisi yang strategis agar upaya penanggulangan kejahatan berjalan secara efektif. Kedua upaya ini harus berjalan bersama (bersinergi) dalam penanggulangan kejahatan.

Barda Nawawi menyatakan bahwa, persoalan adalah bagaimana dapat di integrasikan dan mengharmonisasikan kegiatan atau kebijakan non penal dengan kebijakan penal kearah penekan dan pengurangan faktor-faktor potensial untuk tumbuh suburnya kejahatan. Dengan pendekatan kebijakan yang integral ini diharapkan "sosial defence planning" benar-benar dapat berhasil. Dengan demikian diharapkan pula tercapainya hakikat tujuan kebijakan sosial yang tertuang dalam rencana pembangunan nasional. ${ }^{15}$

\section{a.3. Kebijakan Pertanggungjawaban Pidana}

Sistem pertanggungjawaban pidana dalam perspektif kebijakan kriminal dan kebijakan pidana tidak lepas dari tahap formulasi yang didalamnya

\footnotetext{
${ }^{14}$ Ibid, hlm. 5

${ }^{15}$ Muladi dan Barda Nawawi Arief, “Teori-Teori dan Kebijakan Pidana,” (Bandung: PT Alumni, 1992) hlm.
} 
menyangkut tentang definisi setiap orang yang melakukan tindak pidana. Dan latar belakang seseorang sebagai subjek hukum pidana.

Pada dasarnya hukuman pidana yang dapat dijatuhkan hukum kepada terdakwa sifatnya hanya ada dua macam, yaitu bersifat kumulatif dan alternatif. Pada hukuman yang bersifat kumulatif terdakwa dihukum dengan dua hukuman pokok sekaligus berupa pidana badan dan pidana denda. Sedangkan hukuman yang bersifat alternatif hakim wajib memilih salah satu hukuman, yaitu pidana badan atau pidana kurungan.

Sejalan dengan pembahasan bahwa upaya atau kebijakan untuk melakukan pencegahan dan penanggulangan kejahatan termasuk bidang "kebijakan kriminal" (criminal policy). Kebijakan kriminal ini pun tidak terlepas dari kebijakan yang lebih luas, yaitu kebijakan sosial (social policy) yang terdiri dari upaya/kebijakan untuk kesejahteraan sosial (social walfare policy) dan kebijakan untuk perlindungan masyarakat (social defence policy). Maka, pada situasi pasca dikeluarkannya Kebijakan oleh Menteri Hukum dan Ham berupa Keputusan Menteri Hukum dan Ham No M.HH-19.PK.01.04.04 Tahun 2020, dan juga Permenkumham No 10 Tahun 2020, setidaknya berdampak positif bagi keberlangsungan kegiatan pemasyarakatan yang di selenggarakan di berbagai UPT Pemasyarakatan. Penurunan angka overcrowded di Indonesia, yang menjadi angin segar bagi terselenggara nya sistem pemasyarakatan, selanjutnya juga di dapatkan bahwa negara berhasil menghemat miliaran uang negara dikarenakan narapidana yang dikeluarkan dan di bebaskan, dan dari kebijakan itu pula kesempatan untuk memaksimalkan pembinaan narapidana untuk menjadi lebih produktif dikarenakan keluwesan yang terjadi di dalam Lapas juga bisa dilakukan dengan menghasilkan berbagai keuntungan didalamnya, dan melihat dari situasi dan kondisi seperti ini, pemerintah dalam hal ini Kementerian Hukum dan HAM dirasa sudah melakukan hal yang tepat untuk membantu pemerintah pusat dalam menangani dan menanggulangi pandemi COVID-19 yang sedang terjadi di Indonesia saat ini. 


\section{Upaya Mengurangi Overcrowded Lembaga Pemasyarakatan Pada Masa Pandemi COVID-19}

Pemberian hukuman di penjara memang menjadi salah satu bentuk pelaksanaan pidana. Tempat pelaksanaan hukuman penjara telah berubah istilah menjadi lembaga pemasyarakatan. Hakim yang lebih dominan untuk menjatuhkan hukuman pidana penjara ternyata berdampak sangat signifikan terhadap peningkatan jumlah narapidana di lembaga pemasyarakatan. ${ }^{16}$ Indonesia adalah sebuah negara hukum, didalam sistem peradilan pidana di Indonesia untuk menjalankan pidana bagi pelanggar hukum berada di pemasyarakatan. Pemasyarakatan adalah "sebuah direktorat yang berada di Kementerian Hukum dan HAM untuk membina dan membing para pelanggar hukum yang ada di Indonesia", namun pemasyarakatan mempunyai berbagai hambatan untuk menjalani sebuah pembinaan yaitu overcrowded. ${ }^{17}$

Pemasyarakatan merupakan sistem yang diselenggarakan untuk membina pelanggar hukum agar lebih memperbaiki diri dan dapat diterima kembali di masyarakat. Peningkatan jumlah penghuni lembaga pemasyarakatan dapat memicu adanya permasalahan overcrowded. Kondisi tersebut menyebabkan pembinaan tidak dapat berjalan dengan sebagaimana mestinya sehingga muncul risiko penyimpangan. Overcrowded di lembaga pemasyarakatan juga rentan terhadap penularan COVID-19 yang saat ini masif terjadi.

Untuk mencegah penyebaran di dalam Lembaga Pemasyarakatan(Lapas), Kementerian Hukum dan Hak Asasi Manusia (Kemenkumham) bahkan menetapkan kebijakan lebih awal. Pada tanggal 30 Maret 2020, dikeluarkan Keputusan Menteri Hukum dan HAM NomorM.HH-19.PK.01.04.04 Tahun 2020 tentang Pengeluaran dan Pembebasan Narapidana dan Anak Melalui Asimilasi dan Integrasi Dalam Rangka Pencegahan dan Penanggulangan Penyebaran COVID-19. Di tanggal yang sama juga ditetapkanPeraturan Menteri Hukum dan Hak Asasi Manusia Nomor 10 Tahun 2020 tentang Syarat Pemberian Asimilasi dan Hak Integrasi Bagi Narapidana dan Anak Dalam Rangka Pencegahan dan Penanggulangan Penyebaran COVID-19. Kebijakan ini pada dasarnya mempercepat pemberian hak asimilasi dan pembebasan bersyarat kepada

${ }^{16}$ Ricky Fahriza. “Optimalisasi Tugas Dan Fungsi Pembimbing Kemasyarakatan Dalam Upaya Pencegahan Overcrowded Di Lembaga Pemasyarakatan.”. Jurnal Reformasi Hukum 24(2), 2020. hal 130. DOI: https://doi.org/10.46257/jrh.v24i2.102

${ }^{17}$ Dion Yoas Sitorus. "Strategi Lembaga Pemasyarakatan Dalam Mengatasi Overcrowding". Jurnal Ilmu Hukum dan Humaniora 8(1), 2021. hal 105. DOI: http://dx.doi.org/10.31604/justitia.v8i1.105-111 
narapidana yang telah menjalani 1/2 masa pidana penjara untuk asimilasi atau yang telah menjalani 2/3 untuk pembebasan bersyarat (hak integrasi). Pertimbangan utamanya adalah kondisi overcrowding di Lapas dan Rumah Tahanan (Rutan) yang menyulitkan penerapan Physical Distancingsebagai salah satu upaya utama di dalam mencegah penularan COVID-19.Menteri Hukum dan HAM Yasonna Laoly mengatakan pemberian asimilasi dan integrasi kepada puluhan ribu narapidana tersebut didasari atas alasan kemanusiaan mengingat kapasitas Lapas dan Rutan yang overcrowding. ${ }^{18}$

Berbagai negara lain di dunia juga melakukan kebijakan yang sama, baik negara maju dan negara berkembang. Social Science in Humanitarian Action (SSHA), sebuah organisasi masyarakat yang berbasis di Inggris menjelaskan besarnya risiko penularan COVID-19 di negara-negara berpendapatan rendah dan menengah (Low and Middle Income Countries/LMIC). Hal ini berkaitan dengan kondisi overcrowding serta terbatasnya layanan kesehatan dan kebersihan diri. Keduanya merupakan sebab bagi tinggi risiko penularan yang sulit dikendalikan. Di AmerikaSerikat sendiri, berdasarkan laporan SSHA April 2020, dilaporkan sebanyak 20.000 kasus infeksi di penjara, dengan 243 kasus meninggal dunia. Jumlah temuan kasus di penjara bahkan mencapai 80\% -92\% narapidana ditemukan positif. Gabungan antara angka infeksidan angka kematian mencapai 50\% lebih tinggi daripada kasus di masyarakat umumnya. ${ }^{19}$

Bentuk upaya mengurangi overcrowded di lembaga pemasayarakatan dapat diartikan sebagai upaya negara dalam menekan angka kepadatan melalui kebijakan kriminal. Adapun penyebab tingginya angka kepadatan, yaitu tingkat penjatuhan pidana penjara dapat diatasi jika melakukan analisis secara akurat dan komprehensif. Apabila kebijakan kriminal terkait penganggulangan kejahatan dan sistem pemidanaan dilakukan secara komprehensif, menekankan aspek-aspek yang relevan maka dimungkinkan dapat mengurangi overcrowded di lembaga pemasyarakatan. Overcrowded di lembaga pemasyarakatan menjadi wajar terjadi karena lembaga pemasyarakatan adalah tingkatanterakhir dari sistem pemindanaan dan menjadi bagian penegakan hukum pidana serta pelaksana pidana penjara di Indonesia.

\footnotetext{
${ }^{18}$ Iqrak Sulhin. “Covid-19, Pemenjaraan Berlebihan, Dan Potensi Katastrofe Kemanusiaan.” Jurnal Hukum \& Pembangunan. 5(2), 2020. hal 402. DOI: 10.21143/jhp.vol50.no2.2588

${ }^{19} \mathrm{http} / / /$ www.socialscienceinaction.org/wp-content/uploads/2020/05/SSHAP-COVID_19-Brief-Prisons.pdf. diakses pada 21 Desember 2020 pukul 12:35
} 
Kajian perbandingan tentang hukum merupakan kajian yang membandingkan konsep-konsep dasar dari lembaga hukum yang bersumber dari beberapa sistem hukum asing. Sehubungan dengan studi yang dilakukan maka peneliti mengusulkan untuk menggunakan Good Time Allowance sebagai upaya mengurangi Overcrowded pada lembaga pemasyarakatan. Peneliti dalam kajian ini mengomparasi kebijakan negara asing yang menerapkan Good Time Allowance, yaitu Montana (Amerika Serikat), Wyoming (Amerika Serikat), dan Republik Filipina. Adapun kajian mengenai good time allowance dapat digunakan sebagai alternatif pembinaan penghuni lapas. Good time allowance merupakan perwujudan tindakan non custodial setelah pemidanaan. Kebijakan good time allowance ditujukan untuk menjadi sarana individualisasi sanksi dan rehabilitasi narapidana. Dengan kata lain, kebijakan tersebut hanya dapat mengurangi masa tinggal narapidana di Lapas, bukan mengurangi masa hukuman dari narapidana yang bersnagkutan. Tujuan tersebut tentunya sejalan dengan fungsi sistem pemasyarakatan. Oleh karena itu, sistem pembinaan dengan good time allowance menjadi salah satu alternatif pembinaan yang dapat diterapkan di Indonesia dalam rangka mengurangi overcrowded di lembaga pemasyarakatan..$^{20}$

Kebijakan kriminal yang melibatkan Good Time Allowance dapat digunakan sebagai alternatif menanggulangi kejahatan dengan hukum pidana. Pelibatan good time allowance bertujuan memperbaiki individu plekau tindak kejahatan agar lebih berubah sehingga dapat diterima kembali di masyarakat dengan baik. Apabila model good time allowance diterapkan dengan baik makakebijakan mengurangi masa pidana dengan melakukan suatu pekerjaan baiks sebelumnya dapat digunakan sebagai upaya untuk memotivasi para penghuni lain agar lebih berbuat baik dan tidak lagi mengulangi perbuatan jahatnya di masa lalu. Kebijakan mengurangi masa pidana dengan ketentuan penghuni lapas harus melakukan suatu pekerjaan baik merupakan bagian dari pelaksana pidana penjara melalui program pembinaan penghuni lapas di dalam maupun diluar lembaga pemasyarakatan. Adapun program pekerjaan pembinaan disediakan oleh pemerintah atau lembaga sosial terkait.

${ }^{20}$ Terry Ichwal Nurrohman, “Upaya Mengurangi Overcrowded Lembaga Pemasyarakatan Pada Masa Pandemi Covid-19 Dan Optimalisasi Pembinaan Di Masa Mendatang.” Jurnal Ilmu Hukum dan Humaniora 7 (4), 2020. hal.11. DOI: 10.31604/justitia.v7i4.784-797 


\section{E. PENUTUP}

Pemasyarakatan merupakan sistem yang dislenggarakan untuk membina pelanggar hukum agar lebih memperbaiki diri dan dapat diterima kembali di masyarakat. Peningkatan jumlah penghuni lembaga pemasyarakatan dapat memicu adanya permasalahan overcrowded. Kondisi tersebut menyebabkan pembinaan tidak dapat berjalan dengan sebagaimana mestinya sehingga muncul risiko penyimpangan. Overcrowded di lembaga pemasyarakatan juga rentan terhadap penularan COVID-19 yang saat ini masif terjadi. Dikeluarkannya kebiajakan pemerintah berupa Kebijakan oleh Menteri Hukum dan Ham berupa Keputusan Menteri Hukum dan Ham No M.HH19.PK.01.04.04 Tahun 2020, dan juga Permenkumham No 10 Tahun 2020 merupakan suatu hal yang tepat dan memperoleh dampak yang positif bagi keberlangsungan sistem pemasyarakatan. dari pengurangan narapidana di dalam lapas melalui asimilasi dan Integrasi untuk mencegah COVID-19 bagi narapidana, berhasil menurunkan angka Overcrowded Lapas.

Kebijakan kriminal yang melibatkan good time allowance dapat digunakan sebagai alternatif menanggulangi kejahatan dengan hukum pidana. Pelibatan good time allowance bertujuan memperbaiki individu plekau tindak kejahatan agar lebih berubah sehingga dapat diterima kembali di masyarakat dengan baik. Apabila model good time allowance diterapkan dengan baik makakebijakan mengurangi masa pidana dengan melakukan suatu pekerjaan baiks sebelumnya dapat digunakan sebagai upaya untuk memotivasi para penghuni lain agar lebih berbuat baik dan tidak lagi mengulangi perbuatan jahatnya di masa lalu. Kebijakan mengurangi masa pidana dengan ketentuan penghuni lapas harus melakukan suatu pekerjaan baik merupakan bagian dari pelaksana pidana penjara melalui program pembinaan penghuni lapas di dalam maupun diluar lembaga pemasyarakatan. Adapun program pekerjaan pembinaan disediakan oleh pemerintah atau lembaga sosial terkait. Kebijakan untuk memberi asimilasi dan integrasi kepada narapidana setelah memenuhi syarat-syarat tertentu merupakan kebijakan yang progresif. 


\section{DAFTAR PUSTAKA}

Buku

Barda Nawawi Arief, “Kebijakan Legislatif Dalam Penanggulangan Kejahatan Dengan Pidana Penjara", Yogyakarta: Genta Publishing, 2010.

IS. Heru Permana, "Politik Kriminal”, (Yogyakarta: Universitas Atma Jaya, 2011.

Muladi dan Barda Nawawi Arief, "Teori-Teori dan Kebijakan Pidana", (Bandung: PT Alumni, 1992.

Moh Hatta, "Kebijakan Politik Kriminal Penegakan Hukum Dalam Rangka Penanggulangan Kejahatan”, Yogyakarta: Pustaka Pelajar, 2010.

M. Hamdan, "Politik Hukum Pidana”, Jakarta: PT Raja Grafindo Persada, 1997.

Teguh Prasetyo dan Abdul Halim Barkatullah, "Politik Hukum Pidana: Kajian Kebijakan Kriminalisasi dan Dekriminalisasi”, Yogyakarta : Pustaka Pelajar, 2005.

\section{Jurnal}

Appludnopsanji, Hari Sutra Disemadi. "Problematika Kebijakan Pembebasan Narapidana sebagai Upaya Penanggulangan COVID-19 di Indonesia”, Wawasan Yuridika4(2), 2020. http://dx.doi.org/10.25072/jwy.v4i2.369

Bayu Rizky “Dampak Positif Kebijakan Asimilasi Dan Integrasi Bagi Narapidana Dalam Pencegahan Dan Penaggulangan Covid-19”. Jurnal Ilmu Hukum dan Humaniora 7(3),2020. http://dx.doi.org/10.31604/justitia.v7i3.655-665

Dion Yoas Sitorus. "Strategi Lembaga Pemasyarakatan Dalam Mengatasi Overcrowding”. Jurnal Ilmu Hukum dan Humaniora 8(1), 2021. http://dx.doi.org/10.31604/justitia.v8i1.105-111

Graciella Patras. "Kajian Yuridis Tentang Overcrowded Yang Terjadi Di Lembaga Pemasyarakatan Kelas Ii A Manado Berdasarkan Peraturan Menteri Hukum Dan Hak Asasi Manusia Nomor 11 Tahun 2017'. Jurnal Lex Et Societatis 8(1), 2020. http://dx.doi.org/10.30641/kebijakan.2019.V13.339-358

Iqrak Sulhin. Covid-19, Pemenjaraan Berlebihan, Dan Potensi Katastrofe Kemanusiaan. Jurnal Hukum \& Pembangunan 5(2), 2020.

http://dx.doi.org/10.21143/jhp.vol50.no2.2588

Muhar Jaya. Kebijakan Hukum Pidana terhadap Kedaruratan di Situasi Pandemi COVID-19 Sebagai Alasan Pembebasan Bersyarat. Halu Oleo Legal Research 2(3), 2020. http://dx.doi.org/10.33772/holresch.v2i3.15482

Mohamad Anwar. Asimilasi dan Peningkatan Kriminalitas Di Tengah Pembatasan Sosial Berskala Besar Pandemi Corona. Jurnal Adalah Buletin Hukum dan Keadilan4(1), 2020. http://dx.doi.org/10.15408/adalah.v4i1.15504

Padmono Wibowo. "Pentingnya Mitigasi Risiko Dampak Kepenuhsesakan pada Lapas dan Rutan di Indonesia”. Jurnal Ilmiah Kebijakan Hukum 14(2), 2020. http://dx.doi.org/10.30641/kebijakan.2020.V14.263-283

Ricky Fahriza. “Optimalisasi Tugas Dan Fungsi Pembimbing Kemasyarakatan Dalam Upaya Pencegahan Overcrowded Di Lembaga Pemasyarakatan.”. Jurnal Reformasi Hukum 24(2), 2020. DOI: https://doi.org/10.46257/jrh.v24i2.102

Terry Ichwal Nurrohman, Upaya Mengurangi Overcrowded Lembaga Pemasyarakatan Pada Masa Pandemi Covid-19 Dan Optimalisasi Pembinaan Di Masa Mendatang. Jurnal Ilmu Hukum dan Humaniora 7(4), 2020. 
e-ISSN : 2621-4105

Andika Oktavian Saputra, Sylvester Enricho Mahardika, Pujiyono

http://dx.doi.org/10.31604/justitia.v7i4.784-797

\section{Internet}

https://sulsel.kemenkumham.go.id/berita-kanwil/berita-upt/5288-menyoal-overkapasitas-penjara-di-tengah-tengah-pandemi-covid-19. diakses pada 21 Desember 2020 pukul 12:00

http://www.socialscienceinaction.org/wp-content/uploads/2020/05/SSHAP-COVID_19Brief-Prisons.pdf. diakses pada 21 Desember 2020 pukul 12:35 